\title{
Effects of clam harvesting on sexual reproduction of the seagrass Zostera noltii
}

\author{
Ana Alexandre*, Rui Santos, Ester Serrão \\ Marine Plant Ecology Research Group, CCMAR - Centro de Ciências do Mar, CIMAR - Laboratório Associado, \\ Universidade do Algarve, Gambelas, 8005-139 Faro, Portugal
}

\begin{abstract}
The sexual reproduction of Zostera noltii in the Ria Formosa lagoon (southern Portugal) was assessed by quantifying the variation in both flowering effort and evolution of maturation stages during the fertile season. The effects of clam harvesting on the sexual reproduction of $Z$. noltii were investigated using both descriptive and experimental approaches. Meadows disturbed by clam harvesting were compared with undisturbed meadows in 2 sectors of the lagoon. In both sectors, disturbed meadows showed significantly lower vegetative shoot density and significantly higher reproductive effort. The reproductive effort in the western disturbed meadows was 2-fold higher than in undisturbed meadows, whereas in eastern disturbed meadows it was 4 -fold higher. In disturbed meadows, early maturation stages were found until the end of the flowering season and higher seed production was observed. Both the negative effect of clam harvesting on $Z$. noltii density and the positive effect on its reproductive effort were confirmed by manipulative field experiments. Plots that were experimentally harvested during the fertile season showed significantly lower vegetative shoot density and higher reproductive effort than unharvested plots. Results suggest that Z. noltii responds to clam harvesting disturbance by both increasing its reproductive effort and extending its fertile season.
\end{abstract}

KEY WORDS: Zostera noltii $\cdot$ Clam harvesting $\cdot$ Sexual reproduction $\cdot$ Maturation scale $\cdot$ Disturbance $\cdot$ Flowering Resale or republication not permitted without written consent of the publisher

\section{INTRODUCTION}

Seagrass meadows are important marine habitats, providing food and shelter for a large number of species, and nursery areas for some commercially important fish and shellfish species (Den Hartog 1970, Hemminga \& Duarte 2000). Seagrasses play essential roles in improving coastal water quality, stabilizing sediments, recycling nutrients, and increasing biodiversity (Hemminga \& Duarte 2000). Seagrass beds are recognized as one of the world's natural ecosystems with the highest economic value (Costanza et al. 1997). Disturbance and loss of seagrass habitat have been reported worldwide. Even though some of the declines may result from natural causes, more than $70 \%$ of reported declines are attributed to human-induced disturbances (Short \& Wyllie-Echeverria 1996) related to eutrophication or toxic pollutants. Seagrass meadows are also often damaged by mechanical action related to dredging (Onuf 1994), boat activities such as mooring and pro- peller scars (Zieman 1976, Walker et al. 1989, Dawes et al. 1997, Creed \& Amado Filho 1999), fishing practices (Fonseca et al. 1984, De Jonge \& De Jong 1992, Everett et al. 1995, Boese 2002, Neckles et al. 2005, Uhrin et al. 2005) and trampling (Eckrich \& Holmquist 2000). Mechanical disturbances affect seagrass beds primarily by removing plants, which reduce biomass and has the potential to alter the physical environment.

Certain fishing practices have been shown to reduce seagrass cover (De Jonge \& De Jong 1992, Everett et al. 1995, Boese 2002), particularly in shallow estuaries and tidal lagoons. Commercial clam harvesting is a traditional and economically important activity in the Ria Formosa tidal lagoon (southern Portugal), representing more than $90 \%$ of national clam production (Direcção Regional das Pescas e Aquicultura do Sul pers. comm.). Every day at low tide, clam harvesters dig up intertidal sediments dominated by the seagrass Zostera noltii, using a hand-blade, which breaks and removes the shoots and rhizomes of plants. 
Seagrasses, such as Zostera noltii, colonize space mainly by vegetative growth (Hemminga \& Duarte 2000). However, recently developed genetic tools (Coyer et al. 2004) have shown that the proportion of $Z$. noltii shoots originating from seeds can be as high as $90 \%$ in some meadows (Diekmann et al. 2005), indicating that sexual reproduction can be extremely important in space occupation. Under intense and persistent disturbance, vegetative development may be insufficient to sustain meadows. In this case, the ability to reproduce sexually through flowering and seed development may play a crucial role in the maintenance of meadows. Disturbances, namely burial derived from storms and subaqueous dune migration, increase flowering in the seagrasses Thalassia testudinum (Gallegos et al. 1992) and in Cymodocea nodosa (Marbà \& Duarte 1995).

This study describes temporal variation of sexual reproduction in Zostera noltii in the Ria Formosa throughout the fertile season and investigates the effects of clam harvesting on reproductive effort. This objective was assessed using 2 approaches: (1) comparing the development of flowers and fruits and the maximum reproductive effort of $Z$. noltii in natural meadows under contrasting levels of disturbance by clam harvesting; and (2) testing the effects of experimental clam harvesting on the reproductive effort of $Z$. noltii. To assess the evolution of flowering and fruiting during the fertile season, a maturation scale was developed and temporal variation of the frequency distribution of maturation stages was determined.

\section{MATERIALS AND METHODS}

Study site. Ria Formosa is a mesotidal lagoon, separated from the ocean by a system of 5 sand barrier islands and 6 inlets, which extend for about $55 \mathrm{~km}$ along the south coast of Portugal (Fig. 1). Average water depth is less than $2 \mathrm{~m}$ and tidal amplitudes range from $3.50 \mathrm{~m}$ on spring tides to $1.30 \mathrm{~m}$ on neap tides. As a result, most of the system is exposed at low tide. Bare sediment communities and meadows of the seagrass Zostera noltii occupy the lower intertidal flats.

Maturation scale. A maturation scale was first developed to better understand the developmental stages of the flowers during the flowering season. Flowering shoots were collected from an undisturbed meadow, from the beginning of flowering until it ended. The morphological features of the developmental stages of the flowers were observed in the laboratory using a magnifying lens.

Reproductive outputs. The temporal variation of Zostera noltii flowering effort during the fertile season was evaluated. Cores (12 $\mathrm{cm}$ diameter; $\mathrm{n}=5)$ of $Z$. noltii were randomly collected biweekly in an undisturbed meadow, from the beginning of the flowering season, in June, until no more seed-bearing spathes were found (early November). The percentage of flowering shoots, the number of spathes per flowering shoot, the number of female and male flowers (1 male flower $=2$ thecae) per spathe, the sex ratio, and the reproductive effort were recorded. The number of male and female flowers was counted only in spathes of Stages I and II, because in Stage III some male flowers that had released pollen might have fallen off at the time of sampling.

Effects of clam harvesting. Descriptive study: Two sectors in the Ria Formosa lagoon were considered for this study (Fig. 1): a western sector, where most of the intertidal meadows are easily accessed by the general public, and a less accessible eastern sector, with a great number of private concessions for clam culture. In the western sector, meadows of Zostera noltii are disturbed every day by a large number of private clam harvesters, particularly during the summer months. In contrast, most of the meadows of the eastern sector are less available to people, as they are only accessible by boat. The large number of private concessions also discourages incidental clam harvesting. Anecdotal evidence thus suggests that clam harvest disturbance is lower in the eastern sector than in the western sector.

In each sector, 2 sampling sites were selected: an easily accessible meadow where daily clam harvesting activity occured and a meadow with no clam harvest impact. The 4 sites were sampled biweekly from the beginning of the flowering season, in June, until no more seed-bearing spathes were found (early November). At each site, 5 replicate cores (12 cm diameter) of Zostera noltii were randomly collected. Sampling did not occur on a few particular dates due to logistical problems and thus the number of replicates was not constant through time.

In the laboratory, each core was processed to obtain the density of both vegetative and reproductive shoots. The shoots were dried for $48 \mathrm{~h}$ at $60^{\circ} \mathrm{C}$ and were weighed to determine above-ground biomass. The reproductive effort of Zostera noltii was calculated as the ratio of the dry weight of the reproductive shoots to the total above-ground plant dry weight $\times 100$, i.e. the proportion of total shoot biomass allocated to sexual reproduction (Auby \& Labourg 1996, Kaldy \& Dunton 2000).

A 2-way analysis of variance was used to test significant effects $(p<0.05)$ of disturbance level and sector on vegetative shoot density. Significant effects $(p<0.05)$ of disturbance level on reproductive effort were tested in both sectors using a $Z$-test for proportions (Zar 1999).

Experimental study: Twelve $1 \mathrm{~m}^{2}$ plots (6 treatments and 6 controls) were randomly placed in an undisturbed Zostera noltii meadow. The meadow was 


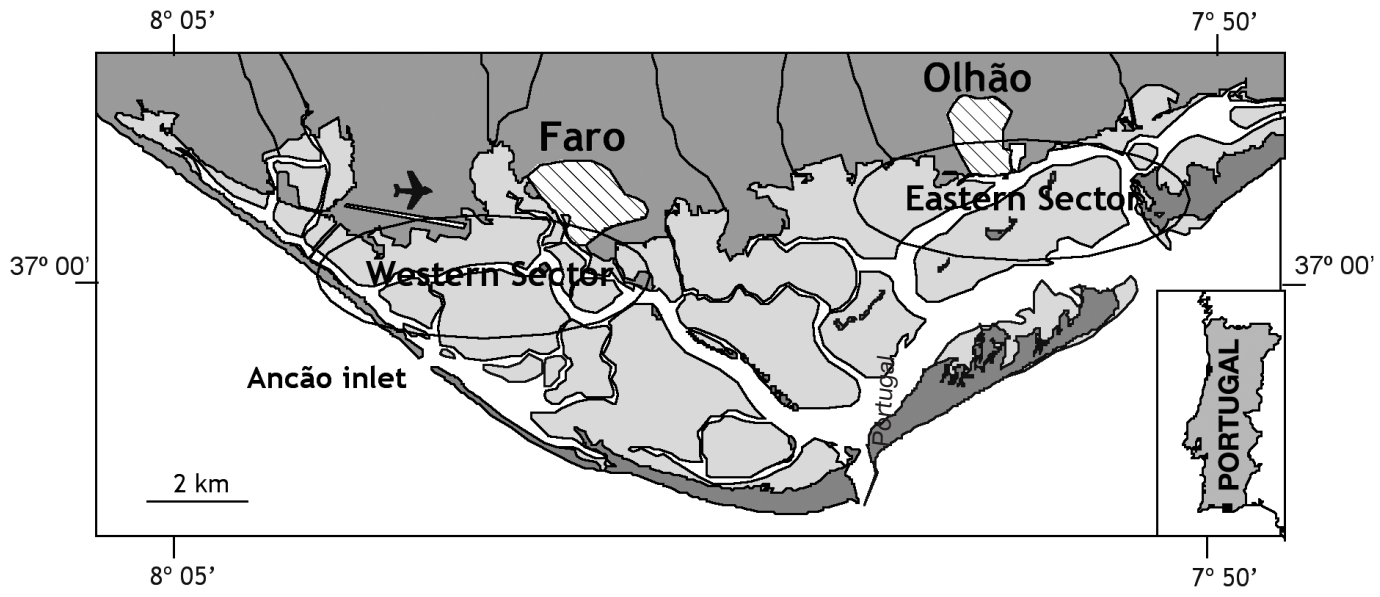

Fig. 1. Ria Formosa with the location of the 2 study sectors studied as well as the Ancão inlet

located in a concession area for clam culture, which assured that no unknown clam harvest occurred in the experimental plots. The experimental treatment consisted of disturbing the plots using the same metal hand blade employed by local harvesters to remove clams. The sediment and the plants were cut to approximately $10 \mathrm{~cm}$ depth and tilled, exposing the plant rhizomes and roots. After experimental disturbance, plots were sampled monthly until the end of the fertile season. During sampling, each plot was divided into $25,20 \times 20 \mathrm{~cm}$, quadrats. Five quadrats were randomly selected in each plot. In the centre of each quadrat, a core (12 cm diameter) was taken and the plant material within the core was extracted. Quadrat coordinates were recorded to assure that future cores were not collected in the same quadrat. In the laboratory, each core was processed as previously described.

There is a possibility that this experimental design generated a disturbance on the neighbouring rhizomes that were longer than $8 \mathrm{~cm}$, the distance between 2 adjacent cores, which corresponded to about 3 internodes. However, it is unlikely that the plants with more than 3 internodes were affected by the cuts. Cabaço et al. (2005, this volume) showed that the experimental shoot fragmentation at different positions along the rhizome had a significant effect on plant survival, rhizome growth and production only when the apical shoot was cut off. Even if there was an effect of cutting the rhizome at the third internode on the reproductive effort of Zostera noltii, the additional cutting resulting from the core collections may have introduced a low level of treatment in the control sampling units. This would decrease the power of detecting the clam harvest effect on the reproductive effort.
A 2-way analysis of variance was used to test significant effects $(p<0.05)$ of treatment and sampling date for vegetative shoot density. Significant effects $(p<0.05)$ of treatment and sampling date for reproductive effort were tested for proportions using a $Z$-test (Zar 1999).

\section{RESULTS}

\section{Maturation scale}

The main morphological features of the developmental stages of flowering and fruiting were classified and organized into a maturation scale (Table 1). Developmental Stages I to IV concern the flowering and pollination phases whereas Stage V concerns the fruiting phase. Stage V was further divided based on the level of maturity of the fruits within the spathe, which was assessed based on their size and colour. Evolution of the frequency distribution of the maturation stages during the fertile season was determined. Within the same spathe there may have been fruits in early stages and fully developed seeds. In those cases, the most advanced stage of maturity was considered.

Table 1. Zostera noltii. Maturation scale of the flowers inside the spathes

\begin{tabular}{|c|}
\hline $\begin{array}{c}\text { Maturation } \\
\text { stage }\end{array}$ \\
\hline Flowering $\left\{\begin{array}{cl}\text { I } & \text { Flowers aligned on a single stem; sheath closed } \\
\text { II } & \text { Mature females erected outside sheath for fertilization } \\
\text { III } & \text { Mature males release filiform pollen (anther dehiscing) } \\
\text { IV } & \text { Fertilized females, thecae empty (if still present) }\end{array}\right.$ \\
Fruiting $\left\{\begin{array}{cl}\mathrm{V} & \text { Presence of fruits } \\
\text { Va } & \text { Small embryos inside the female flowers } \\
\text { Vb } & \text { Fully developed fruit } \\
\text { Vc } & \text { White fruit presents a thin coat } \\
\text { Vd } & \text { Greenish-blue fruit with a hard brownish-black coat: }\end{array}\right.$ \\
\hline
\end{tabular}



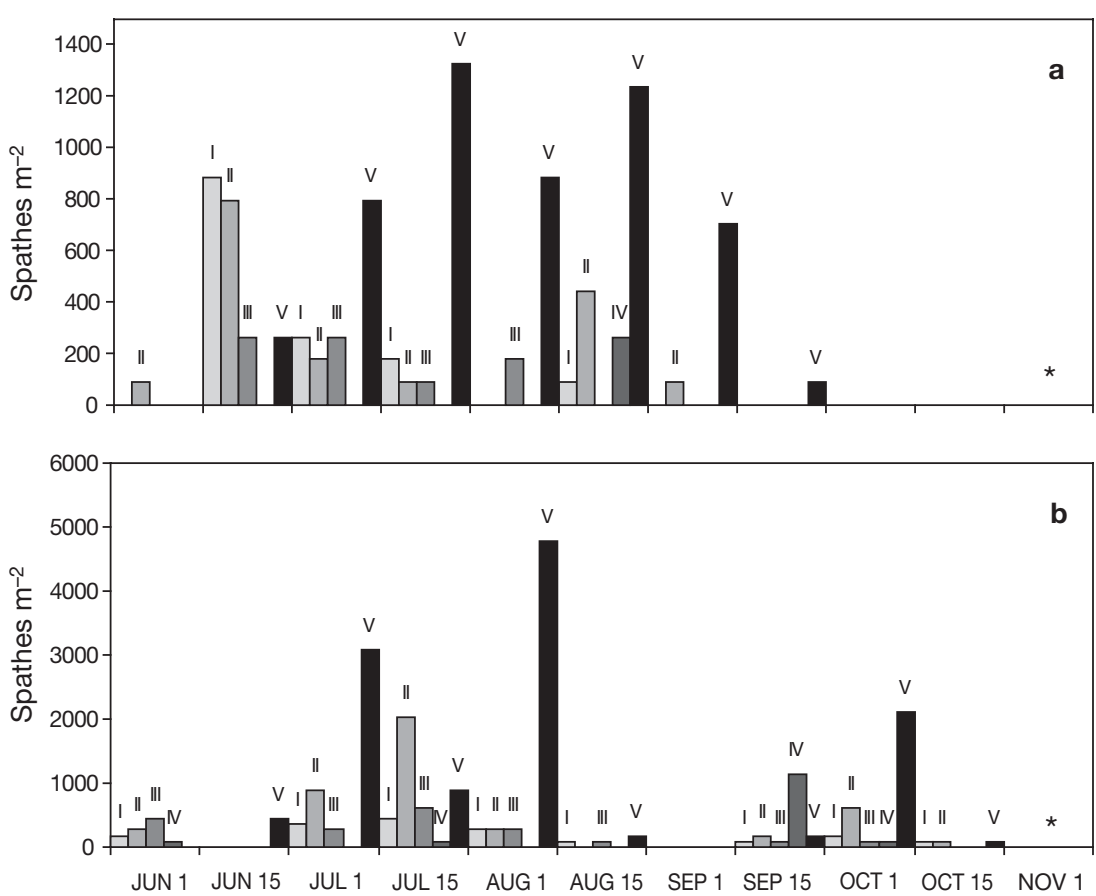

Fig. 2. Zostera noltii. Temporal variation of maturation stages (I to V, Table 1) in (a) undisturbed and (b) disturbed meadows in the eastern sector of the Ria Formosa; (*) not sampled

There was no clear temporal pattern in the percentage of flowering shoots during the fertile season (Table 2). On the other hand, the number of spathes per flowering shoot increased to a maximum of $4.3 \pm 0.48$ in early July and decreased to $1.3 \pm 0.24$ in mid-September. No significant variation pattern was found in the ratio (slightly higher than 1) of male to female flowers during the flowering period (Table 2). In each inflorescence, there was a mean of $4.1 \pm 0.14$ male flowers to $3.5 \pm 0.13$ female flowers. Zostera noltii reached maximum reproductive effort of $1.85 \pm$ $1.14 \%$ in August (Table 2).

Temporal variation in frequency of each maturation stage of Zostera noltii in the Ria Formosa is shown in Fig. 2 (eastern sector) and Fig. 3 (western sector). The presence of early stages throughout the flowering season, from June to September indicates continuous production of flowers. In both sectors, early flower developmental stages shifted to later stages as the flowering season advanced. In June, the earlier stages were predominant,

\section{Reproductive outputs}

The fertile season of Zostera noltii in the Ria Formosa extended from March/April to October/November, with the most intensive flowering from late June to August. Observations made in the year after this study indicate slight variations in the length of the fertile period, with the first flowers developing in late April and persisting until early October. In sandy meadows near the Ancão inlet (Fig. 1), flowers were observed to last until December. but from July onwards the later stages were more abundant. This pattern was less clear in the disturbed meadows. In the undisturbed meadows the earlier stages disappeared from September onwards, whereas in the disturbed meadow all the stages remained present until the end of the flowering season. Moreover, inflorescences at Stage $\mathrm{V}$ were in higher numbers in the disturbed meadows than in the undisturbed ones.

The time needed for a flower to mature, i.e. to reach Stage $\mathrm{V}$, is on the order of $15 \mathrm{~d}$. In both of the undisturbed meadows, this was the elapsed time from the

Table 2. Zostera noltii. Temporal variation of flowering effort during the fertile season (mean \pm SE); 1 male flower $=2$ thecae

\begin{tabular}{|c|c|c|c|c|c|c|c|}
\hline & $\begin{array}{l}\text { Total no. } \\
\text { flowering } \\
\text { shoots in } \\
5 \text { cores }\end{array}$ & $\begin{array}{c}\text { Percentage } \\
\text { flowering } \\
\text { shoots }\end{array}$ & $\begin{array}{c}\text { Mean no. } \\
\text { spathes } \\
\text { shoot }^{-1}\end{array}$ & $\begin{array}{l}\text { Mean no. } \\
\text { thecae } \\
\text { spathe }^{-1}\end{array}$ & $\begin{array}{l}\text { Mean no. } \\
\text { female } \\
\text { flowers } \\
\text { spathe }^{-1}\end{array}$ & $\begin{array}{c}\text { Ratio of } \\
\text { male to female } \\
\text { flowers }\end{array}$ & $\begin{array}{c}\text { Reproductive } \\
\text { effort } \\
(\%)\end{array}$ \\
\hline Jun 1 & 1 & 0.26 & 1.0 & 7.0 & 3.0 & 1.17 & 0.04 \\
\hline Jun 15 & 13 & $3.46 \pm 2.38$ & $2.0 \pm 0.27$ & $8.8 \pm 0.4$ & $3.8 \pm 0.2$ & 1.16 & $1.02 \pm 0.77$ \\
\hline Jul 1 & 4 & $1.72 \pm 1.72$ & $4.3 \pm 0.48$ & $9.0 \pm 0.0$ & $4.0 \pm 0.0$ & 1.13 & $1.16 \pm 1.16$ \\
\hline Jul 15 & 12 & $2.30 \pm 0.85$ & $2.0 \pm 0.25$ & $7.3 \pm 0.9$ & $3.3 \pm 0.3$ & 1.12 & $1.44 \pm 0.73$ \\
\hline Aug 1 & 8 & $1.16 \pm 0.65$ & $1.6 \pm 0.32$ & 0 & 0 & - & $0.29 \pm 0.17$ \\
\hline Aug 15 & 17 & $3.60 \pm 2.47$ & $1.9 \pm 0.32$ & $9.0 \pm 0.8$ & $3.6 \pm 0.6$ & 1.25 & $1.85 \pm 1.14$ \\
\hline Sep 1 & 9 & $1.61 \pm 0.69$ & $1.3 \pm 0.24$ & 8.0 & 3.0 & 1.30 & $0.49 \pm 0.21$ \\
\hline Sep 15 & 1 & 0.36 & 1.0 & 0 & 0 & - & 0.06 \\
\hline
\end{tabular}



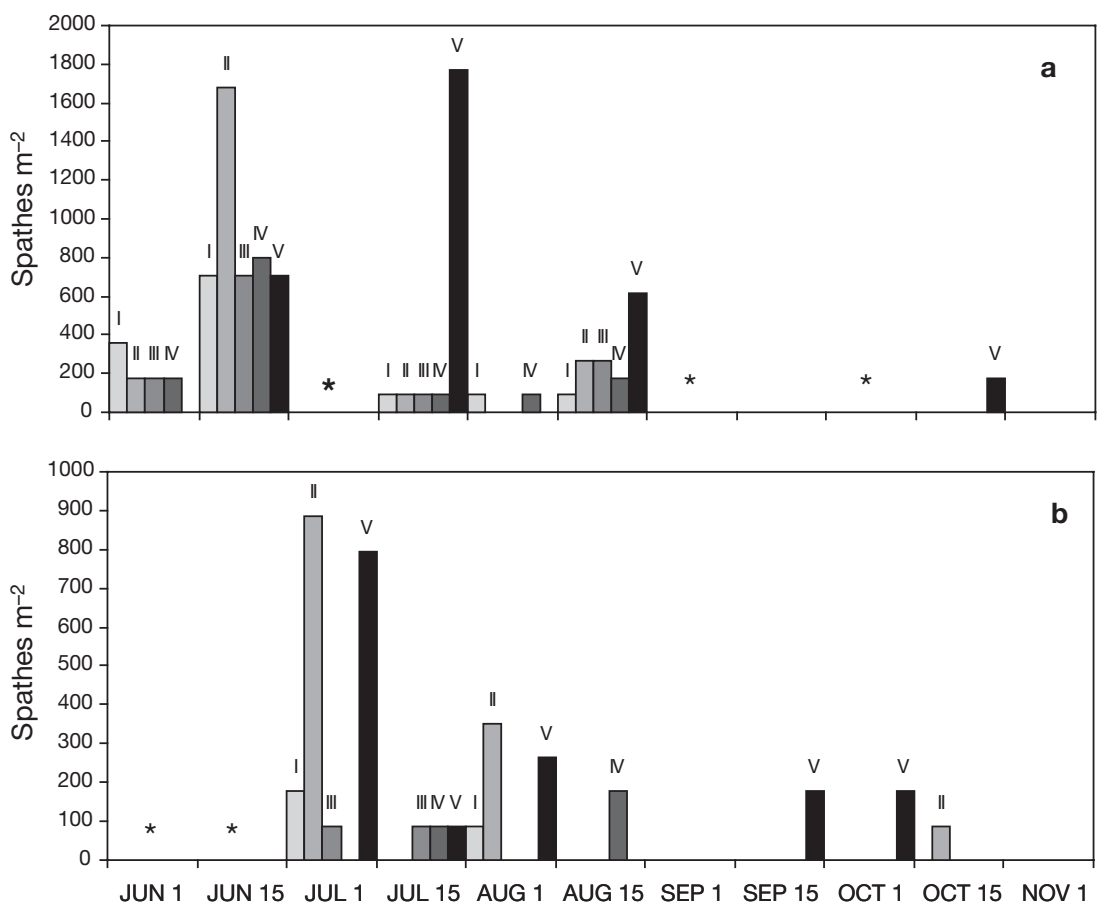

Fig. 3. Zostera noltii. Temporal variation of maturation stages (I to V, Table 1) in (a) undisturbed and (b) disturbed meadows in the western sector of the Ria Formosa; (*) not sampled

beginning of flowers to the first Stage V observed and from the last Stage II to the last Stage V. The time elapsed between the peak of Stages I and II (June 15, Fig. 2a) and the first peak of Stage V (July 1, Fig. 2a) was also $15 \mathrm{~d}$. Zostera noltii seeds may accumulate in Stage $\mathrm{V}$ as there was a series of Stage $\mathrm{V}$ peaks (from July 1 to September 1, Fig. 2a; from June 15 to July 15, Fig. 3a) with no correspondence to previous peaks of Stages I and II.

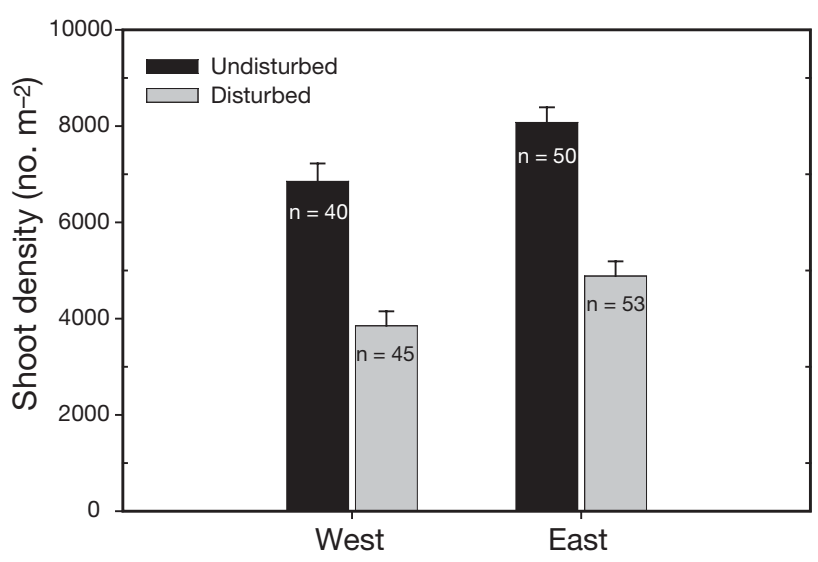

Fig. 4. Zostera noltii. Shoot density in undisturbed and disturbed meadows in the western and eastern sectors of the Ria Formosa $($ mean $+\mathrm{SE}) ; \mathrm{n}=$ number of cores

\section{Effects of clam harvest}

Descriptive study

The average density of Zostera noltii shoots during the flowering season in the eastern sector of the Ria Formosa was significantly higher than in the western sector $(\mathrm{p}<0.001)$. In both sectors, densities in the disturbed meadows were significantly lower $(\mathrm{p}<0.001)$ than in undisturbed meadows (Fig. 4). No significant interaction between sector and disturbance level was found $(p=0.779)$. In the western sector, shoot density in the disturbed meadow ranged from 796 to 7343 shoots $\mathrm{m}^{-2}$ and 3539 to 13366 shoots $\mathrm{m}^{-2}$ in the undisturbed meadow. In the eastern sector, shoot density in the disturbed meadow ranged from 978 to $10106 \mathrm{~m}^{-2}$ and 4600 to 13773 shoots $\mathrm{m}^{-2}$ in the control meadow.

The reproductive effort of Zostera noltii was significantly higher $(\mathrm{p}<$ 0.05) in disturbed meadows than in undisturbed meadows of both sectors (Fig. 5). In the western sector the reproductive effort of the disturbed meadow was 2-fold higher whereas in the eastern sector it was 4 -fold higher. There were no significant differences $(p>0.05)$ in the reproductive effort in undisturbed meadows between sectors, but the reproductive effort was significantly higher $(p<0.05)$ in the eastern disturbed site than in the western disturbed site.

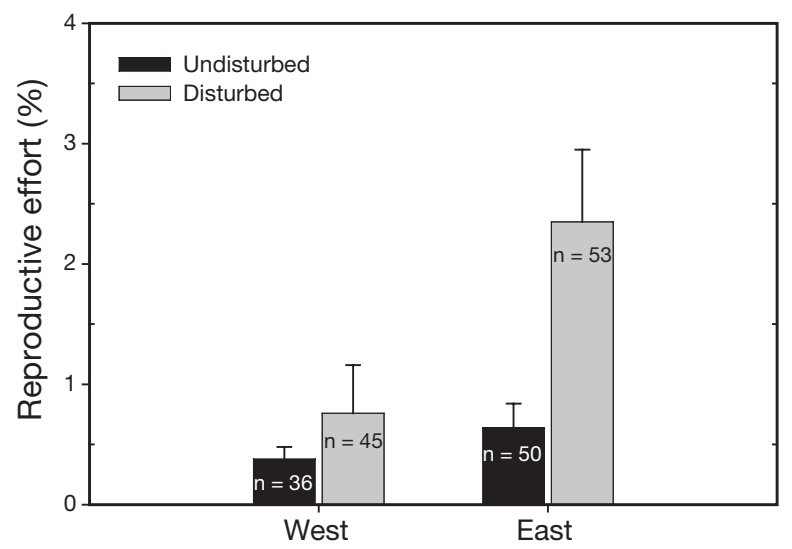

Fig. 5. Zostera noltii. Reproductive effort in undisturbed and disturbed meadows in the western and eastern sectors of the Ria Formosa (mean $+\mathrm{SE}) ; \mathrm{n}=$ number of cores 
Experimental study

Experimental clam harvest had a negative impact on shoot densities of Zostera noltii. Even though there were no significant differences between treatment and control plots 1 mo after the beginning of the experiment (August 2002), in subsequent months (September and October 2002) shoot densities in the harvested plots were significantly lower ( $p<0.001$; Fig. 6). One year after the experiment (August 2003), no significant differences were detected in shoot densities between controls and treatments. No significant interactions were found between treatment and sampling dates $(\mathrm{p}=0.393)$.

There were no significant differences $(p>0.05)$ in the reproductive effort of Zostera noltii between control and treatment plots in August 2002, 1 mo after the treatment (Fig. 7). In all subsequent sampling dates, reproductive effort was significantly higher $(\mathrm{p}<$ 0.05 ) in disturbed plots. Even though the reproductive

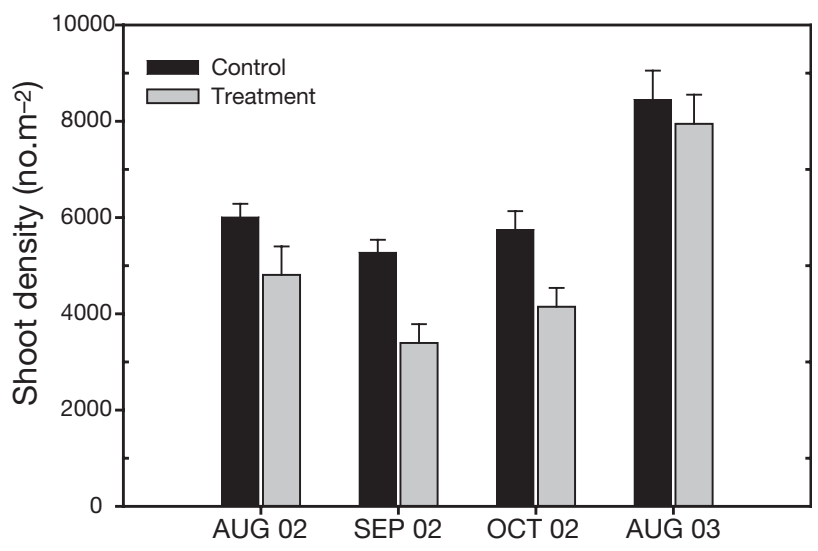

Fig. 6. Zostera noltii. Shoot densities in control and experimental treatment plots (mean $+\mathrm{SE}$ )

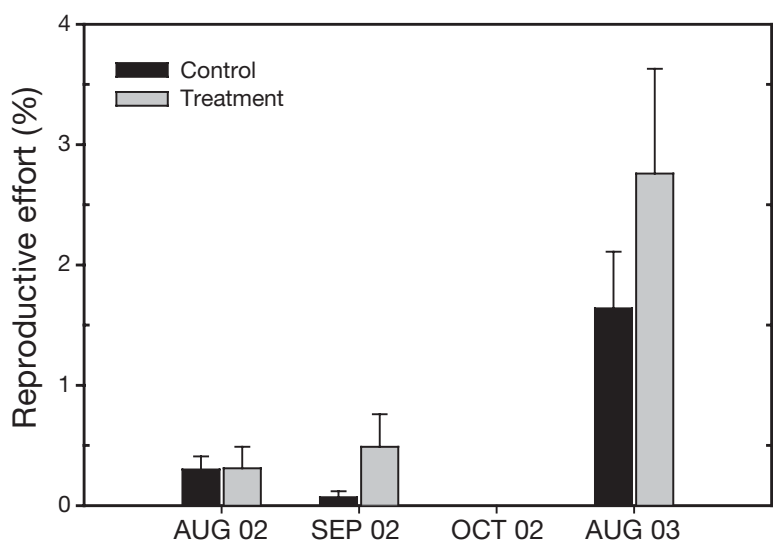

Fig. 7. Zostera noltii. Clam harvest effects on reproductive effort (mean $+\mathrm{SE})$ effort decreased in the controls from August to September as the fertile season was ending, the reproductive effort in treatment plots increased significantly. In October 2002, no more flowers were found in either controls or treatments.

\section{DISCUSSION}

The fertile season of Zostera noltii observed in the Ria Formosa was longer than reported at other geographic locations. Flowers at the Ria Formosa first appeared at the beginning of March and lasted until November, while the flowering season in the Netherlands is from late June to October (Hootsmans et al. 1987) and lasts from May to late August in the Mediterranean (Loques et al. 1988, Curiel et al. 1996). Water temperature, photoperiod, and salinity have been indicated as factors controlling flowering in seagrasses (Loques et al. 1988, Ramage \& Schiel 1999). In the Ria Formosa, the flowering of $Z$. noltii may have been triggered by an increase in water temperature and photoperiod at the onset of spring, while the end of the flowering season coincided with the first heavy rainfalls that occurred in the autumn (authors' pers. obs.). Although the rain does not affect the salinity of the lagoon, there is possibly some direct osmotic stress when the flowers are emerged during low tide. Observations made in sandy areas near the Ancão inlet, where the flowering season lasted until December, support other observations that the $Z$. noltii flowering season lasts longer in sandy sediments of recently colonized meadows (Auby \& Labourg 1996, Curiel et al. 1996). Sediment composition may thus be an additional environmental factor, controlling flowering.

The developmental stages of the flowers and fruits of Zostera noltii in the Ria Formosa and the number of spathes per flowering shoot are nearly identical to those reported by Loques et al. (1988) (4.0 \pm 1.0 in midJune and $5.4 \pm 1.0$ in mid-August) in spite of the geographic and tidal regime differences. In the Mediterranean, $Z$. noltii develops in the subtidal, whereas at the Ria Formosa, meadows are completely emergent at low tide. On the other hand, the percentage of flowering shoots seems to vary widely with geographic location. In the Ria Formosa, percentages varied from $1.16 \pm 0.65$ to $3.60 \pm 2.47 \%$, while Hootsmans et al. (1987) reported values ranging from 1.3 to $9.1 \%$ in the Netherlands and a value of $7.3 \%$ was reported for the Adriatic sea (Curiel et al. 1996). In spite of the lower percentage of flowering shoots recorded for Z. noltii in the Ria Formosa, total reproductive output may not be lower than in other locations as the number of spathes per flowering shoot and the length of the flowering period are among the highest reported for this species. 
The results obtained in this study clearly indicate an adverse effect of clam harvesting on the density of Zostera noltii, as shown by the lower vegetative shoot densities observed in disturbed meadows in both the western and eastern sectors of the Ria Formosa. The lower shoot density and reproductive effort of the western meadows in comparison to the eastern meadows is probably related to a higher human presence. This sector of the Ria Formosa is easily utilized by a large number of visitors, particularly during summer, who trample the meadows and indiscriminately harvest clams and molluscs, which may contribute secondarily to the observed differences. Negative effects of human trampling on seagrass cover, shoot density, and rhizome biomass, have been reported by Eckrich \& Holmquist (2000) for the seagrass Thalassia testudinum, as well as in other plant communities (Monz 2002).

The negative effects of clam harvest disturbance were quite evident in the field immediately after the treatment. The meadow appeared highly tilled and the evidence of tilling persisted 1 mo after the treatment was applied, i.e. sediment mounds were still present on top of the plants. However, the first sign of decreasing densities was only detected 2 mo after the treatment. This is probably due to the fact that shoots damaged by the treatment remained half-buried in the sediment, so that they were included in the first sampling. The sediments mounds were flattened 2 mo after the treatment and so the tidal currents had probably already carried the damaged shoots away.

Since these disturbances (clam harvest and trampling) are frequent and persistent in the Ria Formosa lagoon, particularly in the western sector, the disturbed meadows cannot recover to sustain the high vegetative shoot densities characteristic of the undisturbed meadows. If the disturbance ceased, the Zostera noltii meadows should recover to initial density values, as suggested by our results and those of others (Boese 2002). Nevertheless, disturbance intensity appears to be high in both western and eastern disturbed sites, since these meadows were unable to recover or maintain the shoot densities observed in control sites.

Vegetative shoot densities returned to pre-treatment levels after $1 \mathrm{yr}$, which reveals the great capacity of this species to recover from clam harvest through vegetative development. Zostera noltii has been described as a fast growing species with rapid vegetative recruitment and consequently high recovery rate (Vermaat et al. 1987, Laugier 1999, Peralta 2000). However, recovery depends not only on species biology but also on the intensity and frequency of disturbance (Curiel et al. 1996, Peterken \& Conacher 1997). When disturbance intensity is such that rhizomes and roots are com- pletely removed from the sediment, recovery of the meadows becomes jeopardized, resulting in significant seagrass loss (De Jonge \& De Jong 1992). The frequency of disturbance in this experimental study was lower than that observed during daily clam harvest as the treatment was applied only once at the beginning of the experiment. Moreover, shoots were not totally removed from the sediment. Thus, such observed recoveries are not expected in meadows sustaining daily clam harvesting or in meadows in which the plants are completely removed from the sediment, as is often the case in areas of the Ria Formosa coastal lagoon.

Zostera noltii responded to clam harvest disturbance by increasing its sexual reproductive investment and extending the fertile season to produce more flowering shoots. Other studies have shown the stimulating effect of different types of disturbance on the sexual reproduction of aquatic plants, such as sand burial (Gallegos et al. 1992, Marbà \& Duarte 1995), plant clipping (Crosslé \& Brock 2002), oil spills (Jacobs 1982), sediment anoxia (Plus et al. 2003) and light limitation (Van Lent \& Verschuure 1994), suggesting that plants invest in a high reproductive effort in order to survive in disturbed environments. Theoretical developments also show that annual plants can evolve varied strategies of reproductive timing under unpredictable disturbances by spreading reproduction events over large intervals (Satake et al. 2001).

In conclusion, the clam harvest activity significantly decreased the density of Zostera noltii, increasing the fragmentation of the meadows. The shoot density significantly decreased even in meadows where disturbance was less frequent and intense, as observed in the eastern sector meadows of the Ria Formosa. $Z$. noltii increased its reproductive effort and extended its fertile season as a response to clam harvesting. This effect extended to the next year following manipulations even though densities had returned to control levels suggesting that density is not the main controlling factor of reproductive effort.

Acknowledgements. Our special thanks to A. Quaresma and S. Cabaço, for their field support and valuable comments. We thank Sr. Sousa, for authorizing the field work at his private concession at Marim. This research was funded by the EU Project 'M\&MS-Monitoring and Managing of Seagrass Beds' (EVK3-CT-2000-00044) and FCT, Portugal (PNAT/1999/BIA/ $15003 / \mathrm{C})$.

\section{LITERATURE CITED}

Auby I, Labourg P (1996) Seasonal dynamics of Zostera noltii Hornem. in the bay of Arcachon (France). J Sea Res 35(4): 269-277

Boese B (2002) Effects of recreational clam harvesting on eelgrass (Zostera marina) and associated infaunal inverte- 
brates: in situ manipulative experiments. Aquat Bot 73: 63-74

Cabaço S, Alexandre A, Santos R (2005) Population-level effects of clam harvesting on the seagrass Zostera noltii. Mar Ecol Prog Ser 298:123-129

Costanza R, Arge R, Groot R, Farber S and 9 others (1997) The value of the world's ecosystem services and natural capital. Nature 387:253-260

Coyer JA, Diekmann OE, Serrão EA, Procaccini G, Milchakova N, Pearson G, Stam WT, Olsen L (2004) Genetic differentiation of the seagrass Zostera noltii populations throughout its European, Asian and African range. Mar Ecol Prog Ser 281:51-62

Creed JC, Amado Filho GM (1999) Disturbance and recovery of the macroflora of a seagrass (Halodule wrightii Ascherson) meadow in the Abrolhos Marine National Park, Brazil: an experimental evaluation of anchor damage. J Exp Mar Biol Ecol 235:285-306

Crosslé K, Brock MA (2002) How do water regime and clipping influence wetland plant establishment from seed banks and subsequent reproduction? Aquat Bot 74: 43-56

Curiel D, Bellato A, Rismondo A, Marzocchi M (1996) Sexual reproduction of Zostera noltii Hornemann in the lagoon of Venice (Italy, north Adriatic). Aquat Bot 52:313-318

Dawes CJ, Andorfer J, Rose C, Uranowski C, Ehringer N (1997) Regrowth of the seagrass Thalassia testudinum into propeller scars. Aquat Bot 59:139-155

De Jonge V, De Jong D (1992) Role of tide, light and fisheries in the decline of Zostera marina L. in the Dutch Wadden Sea. Neth Inst Sea Res Publ Ser 20:161-176

Den Hartog C (1970) The seagrasses of the world. NorthHolland, Amsterdam

Diekmann OE, Coyer JA, Ferreira J, Olsen JL, Stam WT, Pearson GA, Serrão EA (2005) Population genetics of Zostera noltii along the west Iberian coast: consequences of small population size, habitat discontinuity and nearshore currents. Mar Ecol Prog Ser 290:89-96

Eckrich C, Holmquist J (2000) Trampling in a seagrass assemblage: direct effects, response of associated fauna, and the role of substrate characteristics. Mar Ecol Prog Ser 201: 199-209

Everett R, Ruiz G, Carlton J (1995) Effect of oyster mariculture on submerged aquatic vegetation: an experimental test in a Pacific North Western estuary. Mar Ecol Prog Ser 125: 205-217

Fonseca MS, Thayer GW, Chester AJ (1984) Impact of scallop harvesting on eelgrass (Zostera marina) meadows: implications for management. North Am J Fish Manage 4: 286-293

Gallegos M, Merino M, Marbà N, Duarte CM (1992) Flowering of Thalassia testudinum Banks ex König in the Mexican Caribbean: age-dependence and interannual variability. Aquat Bot 43:249-255

Hemminga M, Duarte CM (2000) Seagrass ecology. Cambridge University Press, Cambridge

Hootsmans M, Vermaat J, Vierssen W (1987) Seed-bank development, germination and early seedling survival of two seagrass species from The Netherlands: Zostera marina L. and Zostera noltii Hornem. Aquat Bot 28: 275-285

Jacobs RPWM (1982) Reproductive strategies of 2 seagrass species (Zostera marina and Z. noltii) along West European coasts. In: Symoens JJ, Hooper SS, Compère P (eds)
Studies on aquatic vascular plants. Royal Botanical Society of Belgium, Brussels, p 57-62

Kaldy J, Dunton K (2000) Above- and below-ground production, biomass and reproductive ecology of Thalassia testudinum (turtle grass) in a subtropical coastal lagoon. Mar Ecol Prog Ser 193:271-283

Laugier T, Rigollet V, Casabianca ML (1999) Seasonal dynamics in mixed eelgrass beds, Zostera marina L. and $Z$. noltii Hornem., in a Mediterranean coastal lagoon (Thau lagoon, France). Aquat Bot 63:51-69

Loques F, Caye G, Meinesz A (1988) Flowering and fruiting of Zostera noltii in Golf Juan (French Mediterranean). Aquat Bot 32:341-352

Marbà N, Duarte CM (1995) Coupling of seagrass (Cymodocea nodosa) patch dynamics to subaqueous dune migration. J Ecol 83:381-389

Monz CA (2002) The response of two artic tundra plant communities to human trampling disturbance. J Environ Manag 64:207-217

Neckles HA, Short FT, Barker S, Kopp BS (2005) Disturbance of eelgrass Zostera marina by commercial mussel Mytilus edulis harvesting in Main: dragging impacts and habitat recovery. Mar Ecol Prog Ser 285:57-73

Onuf CP (1994) Seagrasses, dredging and light in Laguna Madre, Texas, USA. Estuar Coast Shelf Sci 39:75-91

Peralta G (2000) Estudios sobre el crecimiento en Zostera noltii Hornem.: Dinámica estacional y aspectos ecofisiológicos. PhD dissertation, University of Cádiz

Peterken C, Conacher C (1997) Seed germination and recolonization of Zostera capricorni after grazing by dugongs. Aquat Bot 59:333-340

Plus M, Deslous-Paoli JM, Dagault F (2003) Seagrass (Zostera marina L.) bed recolonization after anoxia-induced full mortality. Aquat Bot 77:121-134

Ramage DL, Schiel DR (1999) Patch dynamics and response to disturbance of the seagrass Zostera novazelandica on intertidal platforms in Southern New Zealand. Mar Ecol Prog Ser 189:275-288

Satake A, Sasaki A, Iwasa Y (2001) Variable timing of reproduction in unpredictable environments: adaptation of flood plain plants. Theor Popul Biol 60(1):1-15

Short FT, Wyllie-Echeverria S (1996) Natural and humaninduced disturbance of seagrasses. Environ Conserv 23:17-27

Uhrin AV, Fonseca MS, DiDomenico GP (2005) Effect of spiny lobster traps on seagrass beds of the Florida Keys National Marine Sanctuary: damage assessment and evaluation of recovery. In: Barnes PW, Thomas JP (eds) Benthic habitats and the effects of fishing. American Fisheries Society, Symposium 41, Bethesda, MD (in press)

Van Lent F, Verschuure JM (1994) Intraspecific variability of Zostera marina L. (eelgrass) in the estuaries and lagoons of the southern Netherlands. I. Population dynamics. Aquat Bot 52:259-281

Vermaat JE, Hootsmans MJM, Nienhuis PH (1987) Seasonal dynamics and leaf growth of Zostera noltii Hornem., a perennial intertidal seagrass. Aquat Bot 28:287-299

Walker DI, Lukatelich RJ, Bastyan G, McComb AJ (1989) Effect of boat mooring on seagrass beds near Perth, Western Australia. Aquat Bot 36:69-77

Zar JH (1999) Biostatistical analysis, 4th edn. Prentice-Hall, Upper Saddle River, NJ

Zieman (1976) The ecological effects of physical damage from motor boats on turtle grass beds in Southern Florida. Aquat Bot 2:127-139

Submitted: January 14, 2005; Accepted: May 26, 2005

Proofs received from author(s): July 28, 2005 